\title{
Analysis of Expert System for Early Diagnosis of Disorders During Pregnancy Using the Forward Chaining Method
}

\author{
Basiroh $^{1}$, Priyatno ${ }^{2}$, Shahab Wahhab Kareem ${ }^{3}$, Heri Nurdiyanto ${ }^{4}$ \\ ${ }^{1,2}$ Informatic Engenering Nahdlatul Ulama University of Cilacap Indonesia \\ ${ }^{3}$ Information System Engineering, Erbil Polytechnic University \\ ${ }^{4}$ Informatic Engenering STMIK Dharma Wacana Metro, Indonesia \\ ${ }^{I}$ Basyirohtest@gmail.com*
}

ARTICLE INFO

Article history:

Received 02-12-2020

Revised 05-01-2021

Accepted 19-07-2021

Keywords:

Expert system

Forward Chaining

Disease

Pregnancy

\section{ABSTRACT}

Now a days technological developments are increasingly having a positive influence on the development of human life, including in the health sector. One of them is an expert system that can transfer an expert's knowledge into a computer application to simplify and speed up the diagnosis of a disorder or disease in humans. The purpose of this final project is to design an application to diagnose diseases that occur during pregnancy which is caused by the existence of these pregnancies to simplify and speed up the diagnosis of diseases experienced by pregnant women. This study uses the forward chaining method. By involving experts in this expert system analysis according to current needs. Users are given easy access to information on several types of pregnancy disorders and their symptoms, as well as consultation through several questions that the user must answer to find out the results of the diagnosis. While experts are facilitated in system management, both the process of adding, updating and, deleting data.

Copyright () 2021 International Journal of Artificial Intelegence Research. All rights reserved.

\section{Introduction}

Pregnancy is happy for the family, but also requires sacrifice[1] that is not easy for a mother. Sometimes pregnancy [2]brings problems to the health of pregnant women. Knowledge of the disorders that occur during pregnancy[1], [3] is needed, especiallyor pregnant women[4], [5], because they are the ones who feel the disturbances [6], [7]directly. The many disorders caused by pregnancy make it difficult to diagnose, especially since some pregnancy disorders have similar symptoms. This causes the time needed to diagnose disorders[8] that occur in pregnant women to be longer, while pregnant women need fast results [9]to find out what disorders they are experiencing. Therefore we need a computer-based [10]tool that can help them to diagnose disorders in pregnancy to be more accurate[11]. With the rapid advancement of computer technology, technology helps people in various fields of life, one of which is the health sector. Currently, computer technology[12] help solves problems that occur, such as performing operations, medical check-ups[13], and others. One of the computer technologies used is Artificial Intelligence (artificial intelligence). One part of an artificial intelligence system [14]is an expert system which is a computer program that mimics expert thinking and knowledge to solve a specific problem[15] The implementation of an expert system is seen as a way of storing expert knowledge in a particular field into a computer program in such a way that it can make decisions[16] and make intelligent reasoning. During its development, expert systems help people in various fields, including in the health sector[17]. Thus, an expert system can be used to assist in diagnosing early pregnancy disorders. [3], [18][19] 


\section{Research Method}

\section{A. Collecting Data}

Andhika Adhitama Gama (2015) [20]Expert system for early detection of website-based Herniated Nucleus Purposes (HNP) uses the Naïve Bayes method[21], in his research he says the system is more accurate, it's just that the drawback is that it is not integrated with a clinic or hospital.

\section{B. Maintaining the Integrity of the Specifications}

\section{Pregnancy}

The following are some definitions of pregnancy:

Pregnancy is the union of sperm from a man and an ovum from a woman. Pregnancy is a period starting from contraception until the fetus is born, the normal length of pregnancy is 280 days, or 9 months and 7 days, which is calculated from the first day of the last menstrual period. Pregnancy is a woman containing a fertilized egg or pregnancy by sperm.

\section{Etiology of Pregnancy}

will occur if there are the following 5 aspects, namely:

Ovum

The ovum is a cell with a diameter of approximately $0.1 \mathrm{~mm}$ consisting of a nucleus floating in the vitellus surrounded by the zona pellucid by Radiata chromosomes.

Spermatozoa

Shaped like a tadpole, consisting of a slightly flattened oval head containing a core, a neck that connects the head to the middle, and a tail that can move so that sperm can move quickly.

Conception a fusion event between sperm and ovum in the fallopian tube.

Nidation

Nidation is the entry or implantation of the product of conception into the endometrium.

Placentation

Placentation is a very important tool for the fetus which is useful for the exchange of substances between mother and child and vice versa.

\section{Signs of pregnancy}

Pregnancy has signs of whether a mother is pregnant or not, here are the signs of pregnancy:

\section{a. Amenorrhea}

If a woman is pregnant when she is already married complains of having late menstruation, then the mind that she is pregnant, despite the stress, drugs, chronic diseases can also result in delayed menstruation.

b. Nausea and Vomiting

Nausea and vomiting are common symptoms, ranging from bad taste to prolonged vomiting. In medicine, it is often called morning sickness because it occurs often in the morning.

c. Matodynia

Is a feeling of tightness and pain in the breasts caused by enlarged breasts?

d. Complaints of urinating

Increased urinary frequency and frequent nighttime urination, caused by the pressure of the enlarged uterus and the cranial pull by the uterus.

e. Change in weight

In 2-3 months of pregnancy, there is often weight loss, due to decreased appetite and vomiting.

f. Changes in basal temperature

g.A rise in basal temperature for more than 3 weeks is usually a sign of pregnancy.

h. Breast changes

i.Due to the stimulation of prolactin and HPL, the breasts secrete colostrum, usually after a gestation of more than 16 weeks.

j. Uterine changes

The uterus changes in size, shape, and consistency. The uterus turns soft and globular in shape.

$\mathrm{k}$. There is a fetal pulse (FHR from 18-20 weeks)

1. Feel the movement of the child (started at 18-20 weeks UK) 


\section{Result}

In advanced reasoning, the rules are tested one by one in a particular order. When every rule is tested, an expert system will evaluate whether the conditions are true or false. If the conditions are correct, then the rule is saved and then the next rule is tested. This process will be repeated until the entire rule base is tested under various conditions. According to Giarattano and Reley (1994), the advanced inference method is very suitable for handling control (controlling) and forecasting (diagnosis). Knowledge in production rules is presented in the form(1):

\section{IF [antecedent] THEN [konsekuen] \\ IF [kondisi] THEN [aksi] \\ IF [premis] THEN [konklusi]}

The rules in the production rule are classified into the first-degree rule and the meta-rule. Rule (2) the first degree is a rule whose concluding part is not the premise of another rule. on the other hand, the meta-rule is a rule whose conclusions are the premise for other rules. The following shows how, how the advanced continuous inference method works.

\section{$\mathrm{A}=1 \quad$ IF $\mathrm{A}=1 \mathrm{AND} \mathrm{B}=2$ \\ $\mathrm{B}=2 \quad$ THEN $\mathrm{C}=3$ AND $\mathrm{D}=4$}

$$
\text { IF } \mathrm{C}=3 \text { THEN } \mathrm{D}=4
$$

\section{A. Knowledge Acquisition}

Table1. Symptom/disease coding matrix

\begin{tabular}{|c|c|c|c|c|c|c|c|c|c|c|c|c|c|c|c|}
\hline \multirow[b]{2}{*}{ No } & SymptomCodes & \multicolumn{14}{|c|}{ Disease Code } \\
\hline & & $\begin{array}{l}0 \\
1\end{array}$ & $\begin{array}{l}0 \\
2\end{array}$ & $\begin{array}{l}0 \\
0 \\
3\end{array}$ & $\begin{array}{l}0 \\
4\end{array}$ & $\begin{array}{l}0 \\
5\end{array}$ & $\begin{array}{l}0 \\
6\end{array}$ & $\begin{array}{l}0 \\
7\end{array}$ & $\begin{array}{l}0 \\
8\end{array}$ & $\begin{array}{l}0 \\
9\end{array}$ & $\begin{array}{l}1 \\
0\end{array}$ & $\begin{array}{l}1 \\
1\end{array}$ & $\begin{array}{l}1 \\
2\end{array}$ & $\begin{array}{l}1 \\
3\end{array}$ & $\begin{array}{l}1 \\
4\end{array}$ \\
\hline 1 & G001 & 1 & 1 & & & & & & & & & & & 1 & 1 \\
\hline 2 & G002 & 1 & 1 & & & & & & & & & & & & 1 \\
\hline 3 & G003 & 1 & & & & & & & & & & & & & \\
\hline 4 & G004 & 1 & 1 & & & & & & & & & & & & 1 \\
\hline 5 & G005 & 1 & 1 & & & & & & & & & & & 1 & 1 \\
\hline 6 & G006 & 1 & 1 & & & & & & & & & & & & 1 \\
\hline 7 & G007 & & 1 & & 1 & 1 & & & & & & & & & 1 \\
\hline 8 & G008 & & 1 & & & & & & & & & 1 & 1 & & 1 \\
\hline 9 & G009 & & 1 & 1 & 1 & 1 & & & & & & & & 1 & 1 \\
\hline 10 & G010 & & 1 & & & & & & & & & & & 1 & 1 \\
\hline 11 & G011 & & 1 & & & & & & & & & & & & 1 \\
\hline 12 & G012 & & & & & & & & & & & & & & 1 \\
\hline 13 & G013 & & 1 & & & & & & & & & & & & 1 \\
\hline 14 & G014 & & & & & & & & & & & & & & 1 \\
\hline 15 & G015 & & & 1 & 1 & 1 & & & & & & & & & \\
\hline 16 & G016 & & & 1 & 1 & 1 & & & & & & & & & \\
\hline 17 & G017 & & & & 1 & 1 & & & & & & & & & \\
\hline 18 & G018 & & & & & 1 & & & & & & & & & \\
\hline
\end{tabular}


G019

G020

G021

G022

G023

G024

G025

G026

G027

G028

G029

G030

G031
$1 \quad 1 \quad 1$

$\begin{array}{llll}1 & 1 & 1 & 1\end{array}$

$1 \quad 1$

$\begin{array}{lll}1 & 1 & 1\end{array}$

11

11

1

1

$\begin{array}{llll}1 & 1 & 1 & 1\end{array}$

$\begin{array}{lll}1 & 1 & 1\end{array}$

explanation :

1. Codes beginning with the letter $\mathrm{G}$ are codes for symptoms.

The following is a description of each code:

\begin{tabular}{|c|c|}
\hline \multirow{2}{*}{ Symptom Codes } & \multirow{2}{*}{$\begin{array}{l}\text { Table Symptom } \\
\text { Table column subhead }\end{array}$} \\
\hline & \\
\hline G001 & Excess headaches \\
\hline G002 & Gaining excess weight \\
\hline G003 & Blood pressure between $140 / 90$ or $160 / 110$ \\
\hline G004 & Proteinuria \\
\hline G005 & Swelling of the face and hands \\
\hline G006 & There is swelling in other parts \\
\hline G007 & Yellow eyes \\
\hline G008 & Pain in the stomach \\
\hline G008 & Nausea and vomiting \\
\hline G009 & Vaginal bleeding \\
\hline G010 & Vaginal bleeding \\
\hline G011 & Blurred vision \\
\hline G012 & Proteinuria +3 \\
\hline G013 & Blood pressure greater than or equal to $160 / 110$ \\
\hline G014 & Convulsions \\
\hline G015 & The tongue is dry and dirty \\
\hline G016 & Vomiting continuously until the mother feels weak \\
\hline G017 & Difficulty defecating \\
\hline G018 & Loss of consciousness \\
\hline G019 & Double vision \\
\hline
\end{tabular}

Basiroh et.al (Analysis of Expert System for Early Diagnosis of Disorders During Pregnancy Using the Forward Chaining Method) 


\begin{tabular}{ll}
\hline \multirow{2}{*}{ Symptom Codes } & \multicolumn{1}{c}{ Table Symptom } \\
\cline { 2 - 2 } G020 & Vagle column subhead \\
\hline G021 & Vaginal bleeding occurs after 20 weeks of gestation \\
\hline G022 & Lower abdominal pain \\
\hline G023 & Upper abdominal pain \\
\hline G024 & Pain that radiates throughout the lower abdomen \\
\hline G025 & Shoulder pain \\
\hline G026 & Pain during bowel movements \\
\hline G027 & There is a lump on the back of the hip \\
\hline G028 & Fresh red blood \\
\hline G029 & colic \\
\hline G030 & Blackish blood \\
\hline G031 & Uterus tense like a plank \\
\hline
\end{tabular}

Codes beginning with the letter $\mathrm{P}$ are codes for disturbances.

The following is a description of each code:

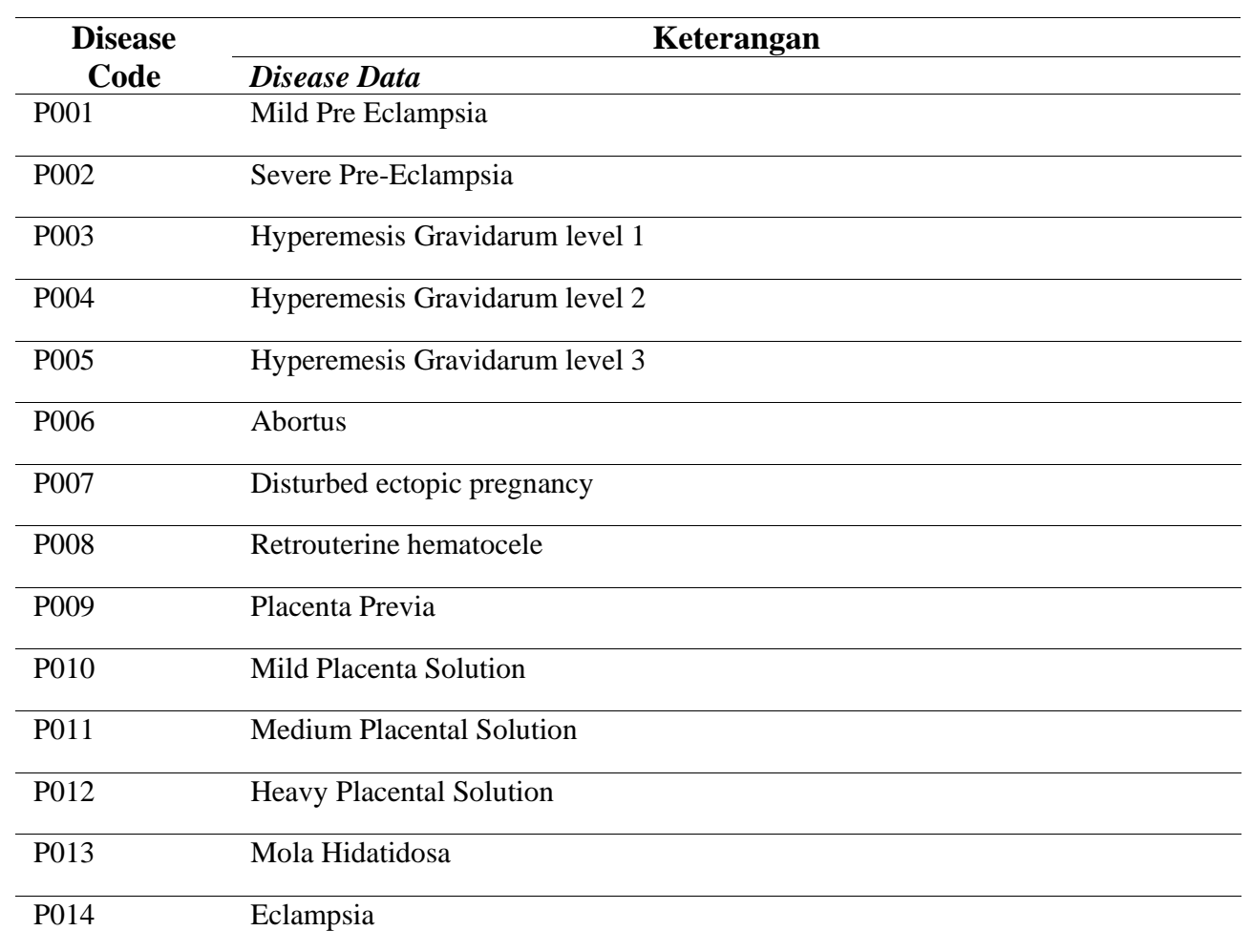

\section{B. Rule Production}

Production rules are usually written in the form if-then (IF-THEN) which can be said to be a twopart implication relationship, namely the premise (if) and the concluding part (then). Premise and conclusion rules can relate to "OR" or "AND". The following are production principles in identifying disease: 
Rule 1 Rule 1

IF Excessive headache '20'

AND Excessive weight gain '20 '

AND Blood pressure between 140/90 or 160/110 '15'

AND Proteinuria '45'

THEN Mild Pre-EclampsiaAturan 2 Rule 2

IF Vomiting continuously until the mother feels weak

AND Vaginal bleeding occurs before 20 weeks of gestation

THEN Impaired ectopic pregnancy

In the case of tracing the decision tree above, there is a problem, that is, not all symptoms can be detected according to the facts in the field, therefore as an expert, give a weight of $50 \%$ if a disease is detected that has a weight of more than $50 \%$ then the disease is detected and if it is less than $50 \%$ doubtful disease.

C. Matrix Value

Symptom / Disease matrix table

\begin{tabular}{|c|c|c|c|c|c|c|c|c|c|c|c|c|c|c|}
\hline \multirow{3}{*}{$\begin{array}{c}\text { Sympt } \\
\text { oms } \\
\text { (G) / } \\
\text { Disease } \\
\text { (P) }\end{array}$} & \multicolumn{14}{|c|}{ Value Table } \\
\hline & P0 & P0 & P0 & P0 & $P 0$ & Po & $\mathbf{P}$ & $\mathbf{P}$ & P0 & P0 & Po & PO & P0 & Po \\
\hline & 01 & 02 & 03 & 04 & 05 & 06 & 07 & $\begin{array}{l}00 \\
8\end{array}$ & 09 & 10 & 11 & 12 & 13 & 14 \\
\hline G001 & 20 & & & & & 30 & & 30 & 20 & 20 & 20 & & & \\
\hline G002 & 20 & & & & & & & & & & 20 & & & \\
\hline G003 & 15 & & & & & & & & & & 15 & & & \\
\hline G004 & 45 & & & & & & & & & & 45 & & & \\
\hline G005 & & 40 & & & & & & & & & & 40 & & \\
\hline G006 & & 30 & & & & & & & & & & 30 & & \\
\hline G007 & & & 45 & & & & & & & & & & 45 & \\
\hline G008 & & & & 40 & & & & & & & & & & 40 \\
\hline G009 & & & & 40 & & & & & & & & & & 40 \\
\hline G010 & & & 40 & & 40 & & & & & & & & 40 & \\
\hline G011 & & & & & & 50 & & & & & & & & \\
\hline G012 & & & & & & 40 & & & & & & & & \\
\hline G013 & & & & & & & 40 & & & & & & & \\
\hline G014 & & & & & & & 30 & & & & & & & \\
\hline G015 & & & & & & & & 45 & 30 & & & & & \\
\hline
\end{tabular}




\begin{tabular}{|c|c|c|c|c|c|c|c|c|c|c|c|c|c|c|c|}
\hline \multirow{3}{*}{$\begin{array}{c}\text { Sympt } \\
\text { oms } \\
\text { (G) / } \\
\text { Disease } \\
\text { (P) }\end{array}$} & \multicolumn{15}{|c|}{ Value Table } \\
\hline & P0 & $\mathbf{P 0}$ & P0 & P0 & $P 0$ & & P0 & $\mathbf{P}$ & $\mathbf{P}$ & P0 & $\mathbf{P 0}$ & P0 & $P 0$ & P0 & P0 \\
\hline & 01 & 02 & 03 & 04 & 05 & & 06 & 07 & $\begin{array}{l}\mathbf{0 0} \\
8 \\
\end{array}$ & 09 & 10 & 11 & 12 & 13 & 14 \\
\hline G016 & & & & & & & & & & 30 & & & & & \\
\hline G017 & & & & & & & & & & & 30 & & & & \\
\hline G018 & & & & & & & & & & & 20 & & & & \\
\hline G019 & & & & & 40 & & & & & & 30 & & & & \\
\hline G020 & 100 & 70 & 85 & 80 & 80 & $\begin{array}{l}5 \\
0\end{array}$ & 70 & 70 & 75 & 80 & 100 & 100 & 70 & 85 & 80 \\
\hline
\end{tabular}

Sample case

Table 5. Sample case

\begin{tabular}{lllcl}
\hline \multirow{2}{*}{ Code } & \multicolumn{4}{c}{ Contoh } \\
\cline { 2 - 5 } & Answer & Weight & Direction & Description \\
\hline G001 & Ya & right & 45 & G002 \\
\hline G002 & Ya & right & 20 & G003 \\
\hline G003 & Ya & right & 15 & G004 \\
\hline G004 & Ya & right & 15 & G001
\end{tabular}

In the case example above the symptoms are met with a weight of $90 \%$, the disease detected is P001 disease.

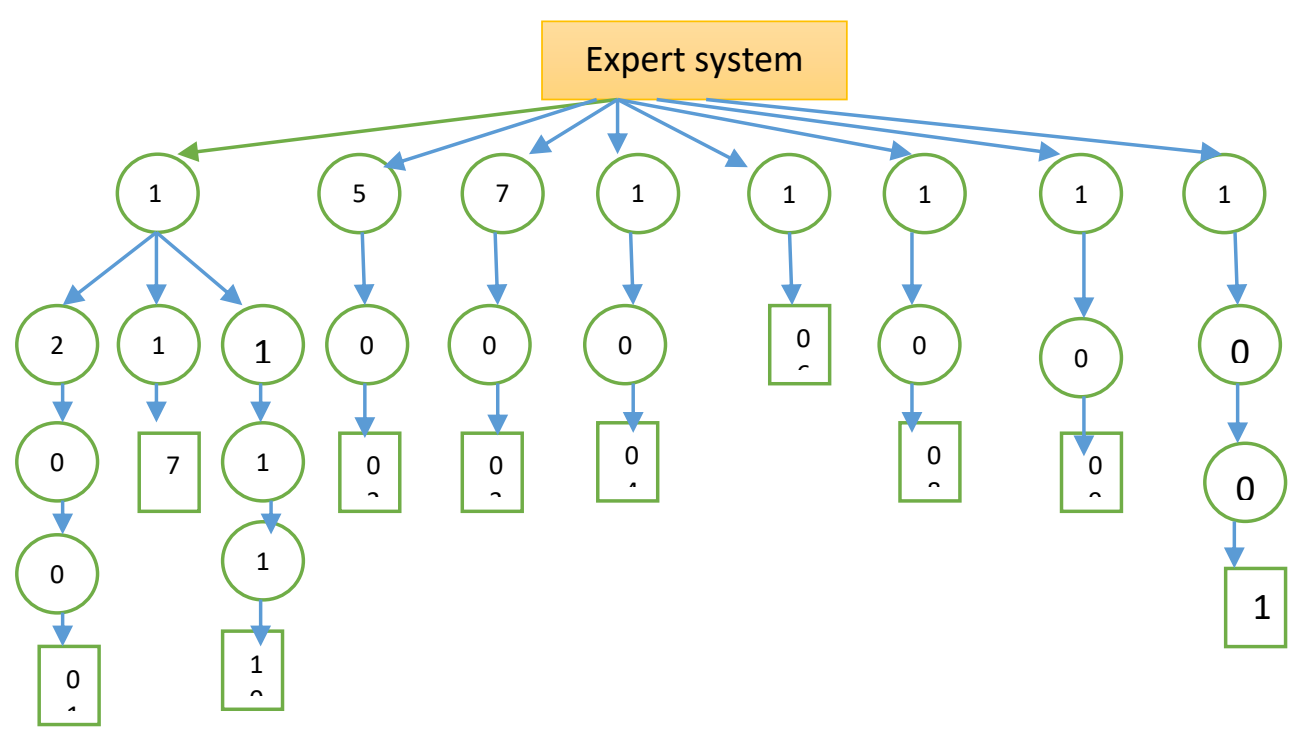

Figure 1. Diagnosis tracking tree for pregnancy symptoms

In Figure 1 above are the symptoms used in the initial question in an expert system for the early diagnosis of pregnancy disorders. If G001 is answered "YES" then it will go to G002 until P001 is found and so on, After the symptoms are grouped according to each disease and an examination is carried out on the knowledge base, the system can provide analysis results in the form of diseases attacked, symptoms that arise and diseases and suggestions for handling them. 


\section{Conclusion}

Expert System for Early Diagnosis of Disorders During Pregnancy Using the forward-chaining approach can help the process of diagnosing pregnancy disorders so that the diagnosis process is faster and this expert system has an output in the form of solutions about disorders that occur during pregnancy and provides explanations, levels of risk, anticipation and methods. treatment that must be done for the disorder that is being experienced. A Suggestion in developing Early Diagnosis of Disorders during Pregnancy with an Expert System Approach is that the making of the matrix should be done automatically by the system to make it easier for experts to analyze the system. The knowledge base of the system, namely data on pregnancy disorders, will be even better if it is added with data from the latest findings or research therefore the results of the diagnosis will be more accurate and the information obtained will be more complete.

\section{Acknowledgment}

Thank you for Universitas Nahdlatul Ulama Cilacap and Departement Minister of Higher Education Innovation and Technology

\section{References}

[1] I. Astuti, H. Sutarno, and Rasim, "The expert system of children's digestive tract diseases diagnostic using combination of forward chaining and certainty factor methods," Proceeding - 2017 3rd Int. Conf. Sci. Inf. Technol. Theory Appl. IT Educ. Ind. Soc. Big Data Era, ICSITech 2017, vol. 2018-Janua, pp. 608-612, 2017.

[2] D. A. Kurniawan, S. W. Sihwi, and Gunarhadi, "An expert system for diagnosing dysgraphia," Proc. - 2017 2nd Int. Conf. Inf. Technol. Inf. Syst. Electr. Eng. ICITISEE 2017, vol. 2018-Janua, pp. 468-472, 2018.

[3] A. Shrestha, A. Anderson, and D. W. Moore, "Using Point-Of-View Video Modeling and Forward Chaining to Teach a Functional Self-Help Skill to a Child with Autism," J. Behav. Educ., vol. 22, no. 2, pp. 157-167, 2013.

[4] K. Rukun, B. H. Hayadi, I. Mouludi, A. Lubis, Safril, and Jufri, "Diagnosis of toddler digestion disorder using forward chaining method," 2017 5th Int. Conf. Cyber IT Serv. Manag. CITSM 2017, 2017.

[5] D. A. Prambudi, C. E. Widodo, and A. P. Widodo, "Expert System Application of Forward Chaining and Certainty Factors Method for the Decision of Contraception Tools," E3S Web Conf., vol. 31, pp. 1-7, 2018.

[6] D. Novaliendry, C. H. Yang, and A. Y. Denno Guara Labukti, "The expert system application for diagnosing human vitamin deficiency through forward chaining method," Int. Conf. ICT Converg. 2015 Innov. Towar. IoT, 5G, Smart Media Era, ICTC 2015, pp. $53-$ 58, 2015.

[7] B. Basiroh and W. Lestari, "Analysis of Plant Fragaria Xananassa Disease Diagnoses Using Production Rules Base on Expert System," J. Pilar Nusa Mandiri, vol. 16, no. 1, pp. 25-32, 2020.

[8] W. Uriawan, A. R. Atmadja, M. Irfan, I. Taufik, and N. J. Luhung, "Comparison of Certainty Factor and Forward Chaining for Early Diagnosis of Cats Skin Diseases," 2018 6th Int. Conf. Cyber IT Serv. Manag. CITSM 2018, no. Citsm, pp. 1-7, 2019.

[9] S. R. Erlina Agustina, Istas Pratomo, Adhi Dharma Wibawa, "2017 International Seminar on Intelligent Technology and Its Application (ISITIA) : proceeding : Surabaya, Indonesia, August, 28-29, 2017.," vol. 2015, pp. 266-270, 2017.

[10] A. S. Pundir and B. Raman, "Dual Deep Learning Model for Image Based Smoke Detection," Fire Technol., 2019. 
[11] m nur hilal Basiroh, "Fakultas Teknik - Universitas Muria Kudus 153," Pros. SNATIF ke-4 Tahun 2017, no. 2015, pp. 153-160, 2017.

[12] M. A. Korany, H. Mahgoub, O. T. Fahmy, and H. M. Maher, "Application of artificial neural networks for response surface modelling in HPLC method development," $J$. Adv. Res., vol. 3, no. 1, pp. 53-63, 2012.

[13] M. Zolnoori, M. H. F. Zarandi, and M. Moin, "Application of intelligent systems in asthma disease: Designing a fuzzy rule-based system for evaluating level of asthma exacerbation," J. Med. Syst., vol. 36, no. 4, pp. 2071-2083, 2012.

[14] A. Jalalian, S. Mashohor, R. Mahmud, B. Karasfi, M. Iqbal Saripan, and A. R. Ramli, "Computer-Assisted Diagnosis System for Breast Cancer in Computed Tomography Laser Mammography (CTLM)," J. Digit. Imaging, vol. 30, no. 6, pp. 796-811, 2017.

[15] R. Manzke et al., "Automatic segmentation of rotational X-ray images for anatomic intraprocedural surface generation in atrial fibrillation ablation procedures," IEEE Trans. Med. Imaging, vol. 29, no. 2, pp. 260-272, 2010.

[16] H. Skutkova, M. Vitek, M. Bezdicek, E. Brhelova, and M. Lengerova, "Advanced DNA fingerprint genotyping based on a model developed from real chip electrophoresis data," $J$. Adv. Res., vol. 18, pp. 9-18, 2019.

[17] C. J. Huang, M. C. Liu, S. S. Chu, and C. L. Cheng, "Application of machine learning techniques to Web-based intelligent learning diagnosis system," Proc. - HIS'04 4th Int. Conf. Hybrid Intell. Syst., pp. 242-247, 2005.

[18] A. Badnjevic, L. Gurbeta, and E. Custovic, "An Expert Diagnostic System to Automatically Identify Asthma and Chronic Obstructive Pulmonary Disease in Clinical Settings," Sci. Rep., vol. 8, no. 1, pp. 1-9, 2018.

[19] E. Eguia, V. Vivirito, A. N. Cobb, H. Janjua, M. Cheung, and P. C. Kuo, "Predictors of Death in Necrotizing Skin and Soft Tissue Infection," World J. Surg., 2019.

[20] P. Yuanita, H. Zulnaidi, and E. Zakaria, "The effectiveness of Realistic Mathematics Education approach: The role of mathematical representation as mediator between mathematical belief and problem solving," PLoS One, vol. 13, no. 9, pp. 1-21, 2018.

[21] W. Siler and J. J. Buckley, "Fuzzy Expert Systems and Fuzzy Reasoning," Fuzzy Expert Syst. Fuzzy Reason., vol. 29, no. Jun, pp. 1-2, 2004. 